\title{
WYBITNY POLSKI BIBLISTA - KS. ALEKSY KLAWEK
}

Dnia 22 listopada $1969 \mathrm{r}$. odszedł od nas nagle, zabierając ze sobą do grobu dużą wiedzę i wielkie doświadczenie naukowe, jeden z najwybitniejszych polskich biblistów ks. Aleksy Klawek, emerytowany profesor Uniwersytetu Jagiellońskiego w Krakowie, a uprzednio profesor Uniwersytetu Jana Kazimierza we Lwowie. Dnia 26 listopada, na cmentarzu w rodzinnym Rogoźnie towarzyszyli zmarłemu w ostatniej drodze zgromadzeni na uroczystościach żałobnych biskupi, księża, lud wierny. Było wśród nich wielu jego uczniów z różnych okresów działalności nauczycielskiej. W poniższym szkicu pragniemy przedstawić zarys jego działalności naukowej i duszpasterskiej, jego wkład do trudnej i odpowiedzialnej gałęzi wiedzy, jaką jest biblistyka, jego zasługi na tym polu, pragnąc w ten sposób uczcić wielkiego uczonego i dobrego człowieka.

Ks. Aleksy Klawek wywodził się z Wielkopolski. Urodzony 11 maja 1890 r. w Rogoźnie, tam też ukończył gimnazjum klasyczne i w 1909 r. wstąpił do Seminarium Duchownego w Poznaniu, gdzie po odbyciu podstawowych studiów teologicznych otrzymał 15 lutego 1913 r. święcenia kapłańskie z rąk biskupa Wilhelma Kloskiego. Po jednorocznym wikariacie $\mathrm{w}$ Wonieściu $\mathrm{k}$. Poznania udał się na dalsze studia teologiczne do Monasteru (Münster) i Monachium, by się specjalizować w zakresie nauk biblijnych, a zwłaszcza Nowego Testamentu. Wyjazd do Monasteru był zdeterminowany dwoma przesłankami: po pierwsze Rogoźno, jak cała Wielkopolska, było pod zaborem pruskim, a odbywanie studiów w obrębie tego samego państwa było łatwiejsze, po drugie w Akademii Monasterskiej wykładało kilku wybitnych uczonych i zapewne ks. Władysław Hozakowski, poznański biblista i pierwszy nauczyciel ks. Klawka, chciał, by jego uczeń pogłębiał swą wiedzę w ośrodku, gdzie studia stały na wysokim poziomie. 
Studia w Monasterze przebiegały gładko i bez zakłóceń. Ks. Klawek słuchał wykładów i brał udział w ćwiczeniach z zakresu Starego Testamentu, prowadzonych przez Wilhelma Engelkempera, i Nowego Testamentu, które prowadził Max Meinertz. Mając zamiar poświęcić się biblistyce nowotestamentowej, swą rozprawę doktorską przygotował pod kierunkiem Meinertza, a za jej temat wziął sobie modlitwę do Jezusa według pism Nowego Testamentu ${ }^{1}$. Doktorat uzyskał w 1917 r. i zaraz po wydrukowaniu części rozprawy w 1918 r. (całość ukazała się dopiero w 1921 r.) stało się światu naukowemu jasne, że biblistyka zyskała w młodym doktorze teologii uczonego, który znakomicie opanował warsztat naukowy i stosuje właściwą metodę badawczą. Po uzyskaniu doktoratu spędził jakiś czas w Monachium i Wrocławiu, pogłębiając swoją wiedzę biblistyczną i orientalistyczną, pracując zarazem nad rozprawą habilitacyjną.

Za temat pracy habilitacyjnej obrał ks. Klawek problem niełatwy, postanowił mianowicie napisać studium egzegetyczne o Bożym Narodzeniu. Monografię tę przygotowywał w latach 1917-19, częściowo podczas pobytu za granicą, częściowo już po powrocie do rodzinnej archidiecezji w 1918 r., kiedy to pełnił obowiązki wikariusza w Granowie i Rydzynie. Niestety tylko jeden rozdział $\mathrm{z}$ tej pracy pt. Noc Betlejemska - historia czy legenda? ${ }^{2}$ ukazał się drukiem. Nie wiemy, co stanęło na przeszkodzie w opublikowaniu całości pracy; czy brak funduszy - były to przecież trudne lata po I wojnie światowej; czy może ks. Klawek uważał, że wyniki jego badań nad Ewangelią św. Eukasza, opisującą dziecięce lata Jezusa, były zbyt nowatorskie i trudne do przyjęcia dla naszego społeczeństwa. Zdawał sobie bowiem dobrze sprawę z tego, że rdzeń opisu Łukaszowego jest historyczny, jednakże historia została przedstawiona w Ewangelii w sposób wolny i celem pierwszorzędnym było zbudowanie czytelnika lub słuchacza. Dlatego nie można na jednym poziomie stawiać historyczności narodzenia Pana Jezusa $z$ epizodami drugorzędnymi, jak np. cała sceneria nocy betlejemskiej. To rozróżnienie przyjmuje dziś egzegeza w całej rozciągłości, ale 50 lat temu zajęcie takiego stanowiska przez młodego biblistę mogło zrazić do autora szerokie kręgi niezbyt dobrze zorientowanych ludzi. Zresztą pewne niemiłe doświadczenie pod tym względem miał ks. Klawek już w 1918 r., gdy „Kurier Poznański” ogłosił jego artykuł pt. Cierniem ukoronowanie Chrystusa Pana, opracowany na podstawie dzieła Jesus vor Pilatus pióra ks. Karola Kastnera. W artykule swym ks. Klawek dowodził, że Ewangelista w rzeczywistości nie mówi o wtłaczaniu cierniowej korony na głowę Jezusa, lecz o włożeniu korony,

1 Das Gebet zu Jesus. Seine Berechtigung und Übung nach den Schriften des Neuen Testaments (Neutestamentliche Abhandlungen VI, 5), Münster i Wrocław 1921.

2 Poznań 1921. 
która nie musiała być cierniowa, ale z ostu. Żołnierze rzymscy urządzili sobie zatem brutalny żart i zadali Jezusowi cierpienia natury raczej morainej niż fizycznej. Przyjęcie tego artykułu, jak również rzeczowej odpowiedzi na anonimową napaść, przekonało ks. Klawka o tym, że niektóre kręgi społeczeństwa jeszcze nie dojrzały do uznania pewnych wyników wnikliwej analizy biblistycznej.

W 1918 r. ks. Klawek został powołany na wykładowcę Pisma św. w Seminarium Duchownym w Gnieźnie, a niebawem, gdy ks. arcybiskup Dalbor wznowił studia w Seminarium Duchownym w Poznaniu i tworzył osobną katedrę Pisma św. Nowego Testamentu, przeniósł się do Poznania. Wówczas to w maju 1919 r. na życzenie arcybiskupa przedstawił szczegółowy plan trzyletniego studium nowotestamentowego ${ }^{3}$. Plan ten wykazuje świetną orientację młodego profesora w problematyce nowotestamentowej biblistyki, przy czym uwzględnia w szerokim zakresie tło historyczne, dobrze rozbudowane podstawy filologiczne i patrystyczne. Opracowywane przez siebie studium biblijne wzbogacił ks. Klawek przez prowadzenie naukowego seminarium $\mathrm{z}$ Nowego Testamentu, co na gruncie poznańskim było całkowitą nowością ${ }^{4}$.

Oprócz działalności dydaktycznej na terenie Seminarium Duchownego rozpoczął żywą działalność w Wydziale Teologicznym Poznańskiego Towarzystwa Przyjaciół Nauk, ściśle współpracując z inicjatorem i założycielem tego wydziału, a swoim dawnym profesorem, ks. Hozakowskim. W grudniu 1921 r. został wiceprezesem tego wydziału, a ponieważ stanowisko prezesa po rezygnacji ks. Hozakowskiego pozostawało nieobsadzone, praktycznie kierował pracami wydziału. Równocześnie rozwijał żywą działalność pisarską, omawiając szereg prac biblistycznych oraz polski przekład Ewangelii i Dziejów Apostolskich, dokonany przez ks. W. Szczepańskiego ${ }^{5}$. Już w owym czasie daje się w jego wypowiedziach zauważyć nacisk położony na konieczność dokonania nowego przekładu całego Pisma św. na język polski. Motyw ten będzie powtarzał się w jego wypowiedziach przez długi czas.

Praca naukowa ks. Klawka w Poznaniu wiązała się z myślą o działalności uniwersyteckiej, gdyż wówczas prowadzone były starania o otwarcie wydziału teologicznego na świeżo utworzonym uniwersytecie. Gdy jednak ostatecznie do utworzenia tego wydziału w Uniwersytecie Poznańskim nie doszło, przyjął ks. Klawek w 1923 r. katedrę Pisma św. Starego Testamentu na Uniwersytecie Jana Kazimierza we Lwowie. Przedtem wyjechał na pół roku do Paryża, gdzie pogłębiał swą wiedzę

3 Ks. Marian Wolniewicz, Biblijna działalność ks. prof. Klawka w Wielkopolsce 1917-1923, RBiL XXIII, 1970, 269.

4 Tamże, 270.

5 Tamże, 272. 
z zakresu assyriologii i historii Starożytnego Wschodu. Równocześnie zapoznał się wówczas $\mathrm{z}$ osiągnięciami biblistyki francuskiej, kierowanej przez wybitnego uczonego o. M. J. Lagrange'a, dominikanina, którego zasługi omówił w specjalnym artykule ${ }^{6}$.

16 lat pracy na Uniwersytecie Jana Kazimierza (1923-1939) to okres bardzo wytężonej i wielostronnej działalności. Posuwał się naprzód w karierze akademickiej, otrzymując po profesurze nadzwyczajnej profesurę zwyczajną, piastując przez dwa lata urząd dziekana Wydziału Teologicznego, a w roku akademickim 1933/34 godność prorektora uniwersytetu. Zaraz po przyjeździe do Lwowa objął w 1923 r. redakcję „Przeglądu Teologicznego", przekształcając go następnie w czasopismo o charakterze międzynarodowym pt. „Collectanea Theologica” (od 1931 r.). W piśmie tym, redagowanym $w$ jezzykach obcych, informował zagranicę o pracach polskich teologów. Leżało mu bowiem bardzo na sercu odpowiednie zorganizowanie pracy teologów w Odrodzonej Polsce i w tej dziedzinie chyba największą zasługą było zorganizowanie razem z ks. ks. Szcz. Szydelskim, Długoszem, Stachem i innymi profesorami pierwszego zjazdu teologów polskich w kwietniu $1928 \mathrm{r} .{ }^{7}$ Zjazd ten, na którym wygłoszono 39 referatów, opublikowanych następnie w 1930 r. we Lwowie pt. Nasza myśl teologiczna, uznać trzeba za punkt zwrotny w pracy naszych teologów. Pasja organizatorska ks. Klawka znalazła swój wyraz w przygotowaniu i zorganizowaniu pierwszej naukowej wycieczki księży polskich do Ziemi Swiętej w 1934 r. ${ }^{8}$

Uniwersytet Jana Kazimierza zyskał w osobie ks. Klawka wybitnego uczonego, nieprzeciętnego dydaktyka, rozmiłowanego w swoim przedmiocie badacza naukowego, a młodzież akademicka oddanego przyjaciela i opiekuna. „Dzięki właściwościom charakteru zjednał sobie wkrótce uznanie i szacunek $\mathrm{w}$ kołach nie tylko kolegów z teologii, ale także wśród profesorów innych wydziałów, humanistycznego w pierwszym rzędzie, ale także przyrodniczego, również medycznego" 9. Cytowani przyjaciele ks. Klawka z tego okresu piszą dalej: „Wysunęliśmy na plan pierwszy poza teologią Wydział Humanistyczny jego sercu szczególnie bliski, uprawiał bowiem ks. Klawek obok biblistyki w ścisłym tego słowa znaczeniu świecką filologię orientalną, której różne działy jeszcze przed r. 1939 wykładał chętnie w Instytucie Orientalnym Uniwersytetu Jana Kazimierza, po wojnie zaś w katedrze Filologii Orientalnej Uniwersytetu Jagiellońskiego" 10. Do przyjaciół jego, z których tu wymienimy tylko

6 Tamże, 274.

7 Ks. Stanisław Grzybek, Sp. ks. prof. Aleksy Klawek (1890-1969), RBiL XXIII, 1970, 261.

8 Tamże.

9 Jerzy Kuryłowicz, Witold Taszycki, Ks. prof. Aleksy Klawek w oczach kolegów świeckich, TP XXIII, 1969, nr 50 (1090).

10 Tamże. 
niektórych, zaliczali się wybitni uczeni, często o międzynarodowej sławie. Pierwsze więzy przyjaźni nawiązał jeszcze w Poznaniu w 1919 r. z wybitnym polonistą i slawistą, Tadeuszem Lehrem-Spławińskim, później profesorem we Lwowie i Krakowie. Już we Lwowie do grona jego przyjacioł zaliczali się prof. prof. Jerzy Kuryłowicz, Witold Taszycki — wybitni językoznawcy, archeolog i filolog klasyczny Edmund Bulanda, antropolog Jan Czekanowski, farmakolog Włodzimierz Koskowski, medyk Roman Rencki, filolog klasyczny Jerzy Kowalski, slawista Jan Janów, astronom Zygmunt Rybka, romanista Zygmunt Czerny, a z młodszych orientaliści Marian i Tadeusz Lewicki, oraz historyk Karol Lewicki. Ze wszystkimi spotykał się na polu pracy naukowej i organizacyjnej. Spośród kolegów z Wydziału Teologicznego cieszył się dozgonną przyjaźnią ks. ks. Gerstmana, Stacha, Szydelskiego i Długosza.

Stosunkowo wcześnie, bo już w 1926 r., miałem możność jako student Wydziału Teologicznego zapoznać się osobiście z ks. Klawkiem, który wówczas wykładał egzegezę ksiąg Starego Testamentu, język hebrajski i archeologię, a na Wydziale Humanistycznym prowadził zajęcia z filologii semickiej. Dla początkujących studentów był bardzo groźny: zapominał bowiem, że słuchaczami są studenci nie obeznani ani z metodami pracy naukowej, ani nie oczytani w bieżącej, zwłaszcza zachodniej, literaturze biblistycznej. Poprawne odpowiedzi natychmiast nastrajały go przyjaźnie.

$\mathrm{Na}$ jego seminaria zapisywało się niewielu słuchaczy spośród studentów teologii i dlatego swe zajęcia prowadził razem ze świeckimi. Na zajęcia uczęszczali tė̇ Żydzi, m. in. rabin Salz. Seminarium dla zaawansowanych prowadził ks. Klawek zwykle u siebie w domu przy ul. Supińskiego 11, częstując uczestników herbatą. Już wówczas myślał stale ks. Klawek o nowym polskim przekładzie Pisma św., jednakże z braku odpowiednich współpracowników nie mógł rozpocząć dzieła; dopiero gdy wychował wielu uczniów, po drugiej wojnie światowej zaczął realizować swe dawne plany.

Nieco uwagi wymaga stosunek ks. Klawka do Biblii, a specjalnie do Starego Testamentu. W swych wykładach podkreślał zawsze, że Biblia to Słowo Boże, ale zarazem księga ludzka nie tylko ze względu na okoliczności, w jakich powstawała, i ze względu na cechy literackie, jakimi się odznacza, lecz także dlatego, że jest odbiciem życia prawdziwych ludzi. Ludzki czynnik w Piśmie św. widać nie tylko w treści moralnej, odciśnięty jest tu także głęboko indywidualizm poszczególnych pisarzy - autorów. Świadczy to o tym, że świat biblijny nie jest światem zamkniętym, pozbawionym łączności z otaczającą go kulturą materialną i literacką sąsiednich ludów. Twórczości, która swe źródło ma w wyobraźni, udzielają się braki tego rodzaju literackiego. Ksiegi Rut, Tobiasza, Estery, 
a nawet - chociaż z innego nieco względu - Jonasza należą do literatury budującej i zawierają elementy zmyślone. Jednakże nie możemy ich traktować tak jak dzisiejszych powieści czy legend. Dawna literatura imaginacyjna nigdy nie jest w zupełności wymyślona, Semita bowiem pisząc nigdy nie zbacza $\mathrm{z}$ drogi konkretu. Fikcja rozgrywa się wokół elementu mniej lub bardziej trwałego, który może być otoczony motywami o zabarwieniu legendarnym na podłożu ludowym. Linia podziału między literaturą historyczną a zmyśloną jest więc na Wschodzie mniej wyraźna niż u nas. Trzeba zatem w każdym wypadku starać się wykryć właściwy charakter, jaki danemu rodzajowi literackiemu pragnął nadać geniusz semicki.

Poszczególne księgi Starego Testamentu w różnym stopniu przyciągały uwagę ks. Klawka. Dużo wysiłku i pracy włożył we właściwe zrozumienie Pięcioksięgu, przede wszystkim Genesis, ale z biegiem czasu jego uwagę zaabsorbowała w większym stopniu literatura profetyczna i psalmy. Prorocy, jego zdaniem, doprowadzili religię Starego Testamentu do wielkiego rozkwitu. Ich zadania były różnorakie. Po pierwsze bronili religii przed zniekształceniami i bałwochwalstwem. Oni kładli podwaliny teologii staro- i nowotestamentowej. Rozwinęli pojęcie miłości Boga do ludzi. Głosili oni: „Bóg miłuje nie tylko naród, ale każdego poszczególnego człowieka"; podczas gdy uprzednio dbano tylko o naród, o spoleczeństwo, a nie było troski o religię jednostki. Dopiero Ozeasz i Ezechiel wprowadzili indywidualizację religii. Następne zadanie proroków polegało na pogłębieniu spraw etycznych. Głosili oni, że normą dla postępowania człowieka jest Bóg. W przeciwstawieniu do antroponomicznych ujęć Greków, religia objawiona jest teonomiczna. Wielki też był udział proroków w spełnianiu zadania społecznego. Często byli oni obrońcami ludu przed uciskiem królów i możnowładców, brali w opiekę osoby upośledzone, jak wdowy, sieroty i biednych. Broniąc religii stawali się czasem politykami (Jeremiasz) ${ }^{11}$.

Analizując psalmy mocno podkreślał ks. Klawek ważność tej księgi Pisma św. dla chrześcijan. Psatterz to modlitewnik pierwszych chrześcijan, uświęcony ustami Chrystusa Pana, bo przecież słowami psalmów modlił się Boski Mistrz po Ostatniej Wieczerzy i na krzyżu.

W okresie lwowskim nie ograniczał się ks. Klawek do wspomnianej wyżej działalności organizacyjno-naukowej i pedagogicznej. Następną dziedziną, której się poświęcił z dużym zapałem i poświęceniem, było zorganizowanie duszpasterstwa akademickiego dla studentów Lwowa.

11 Por. E. Meyer, Ursprung und Geschichte der Mormonen, Heidelberg 1912; G. Hölscher, Die Propheten, Lipsk 1914; H. Junker, Prophet und Seher in Israel, Trier 1927; A. Halder, Association of Cult Prophets among the Ancient Semites, Uppsala 1945; J. Lindblom, Prophecy in Ancient Israel, Oxford 1962; L. Dürr, Wollen und Wirken der alttest. Propheten, Düsseldorf 1926. 
Lwów w owym czasie był drugim po Warszawie skupiskiem wyższych uczelni w Polsce z liczną (ponad 7 tysięcy) młodzieżą studiującą. Ks. Klawek, przywiązując dużą wagę do formowania właściwej postawy młodej inteligencji katolickiej, pragnął, by młodzież uniwersytecka była czynna i dynamiczna pod względem religijnym, uwrażliwiona na wartości realnego życia, a równocześnie dostrzegająca jego nadprzyrodzone perspektywy. Pracę w tej dziedzinie rozpoczął już w 1927 r., gdy reprezentanci stowarzyszeń akademickich zwrócili się do niego i ks. Gerstmana z prośbą o zorganizowanie Duszpasterstwa Akademickiego. Wprawdzie istniały sodalicje studentów i studentek oraz organizacja pod nazwą "Odrodzenie", ale nie wywierały one większego wpływu na ogół studentów. Ponieważ we Lwowie nie było osobnego kościoła akademickiego, rzucił ks. Klawek myśl budowania kaplic w domach studenckich. Jego inicjatywa została podjęta w 1933 r. przez Bratnią Pomoc Politechniki w II Domu przy ul. Abrahama. Projekty wykonali studenci, sami też zajęli się zwózką kamieni, cegły i piasku. Dzień poświęcenia kaplicy, tj. 2 grudnia 1934 r., był datą przełomową w życiu religijnym lwowskiej młodzieży akademickiej. Dwa lata później, w 1936 r., ukończona została kaplica w domu studentek, ozdobiona pięknym witrażem według projektu Reginy Szyrajer. W 1937 r. wybudowana została trzecia kaplica w domu przy ul. Pijarów. W tych kaplicach we wszystkie niedziele i święta, oraz jeden raz w tygodniu, ks. Klawek i inni księża profesorowie, i asystenci odprawiali msze święte, a w maju prowadzili nabożeństwa majowe. W Wielkim Poście duszpasterstwo akademickie urządzało rekolekcje, w których brało udział ponad 40 procent młodzieży, przystępując do wspólnych sakramentów świętych. Urządzał także ks. Klawek rekolekcje zamknięte dla młodzieży, w czym z pomocą przyszli dominikanie, użyczając dla tego celu swoich klasztorów w Podkamieniu i Jarosławiu. W 1936 r. zorganizował ogólnoakademicką pielgrzymkę na Jasną Górę i wtedy ogłoszono Maryję patronką młodzieży akademickiej.

Ponieważ w okresie międzywojennym warunki materialne większości studiującej młodzieży były ciężkie, ks. Klawek dokładał starań, by potrzebującym przyjść z pomocą. Wraz z księżmi Stachem i Szydelskim skutecznie pomagał młodzieży na Uniwersytecie, Politechnice i Akademii Weterynarii zakładając stowarzyszenie "Caritas Academica”. Zajmowal się studentami chorymi, zwłaszcza na gruźlicę, umieszczając ich w sanatorium w Mikuliczynie, gdzie w kaplicy, o którą się zatroszczyć nie omieszkał, odprawiał mszę świętą, odwiedzając chorych i podnosząc ich na duchu. Cieszył się bardzo, gdy jego działalność znajdowała oddźwięk, (np. gdy młodzież w II Domu Techników postarała się o 300 prostych drewnianych krzyży, rozwieszając je na ścianach). Troska ks. Klawka 
o młodzież i jej potrzeby była wyrazem rzetelnego i prawdziwego zrozumienia jej spraw oraz miłości, jaką ją darzył.

Druga wojna światowa przerwała naukową, redaktorską i społeczną działalność ks. Klawka. Aresztowany w Rogoźnie, dokąd wyjechał na wakacje ze Lwowa, przebywał w VII Forcie pod Poznaniem jako więzień gestapo. Na prośbę ks. Stacha, potwierdzoną przez Kreisamt w Limanowej, oraz ks. Smereki, potwierdzoną z kolei przez Kreisamt w Dębicy, został zwolniony pod warunkiem, że opuści Poznańskie i zamieszka w GG. Tu został przyjęty przez diecezję tarnowską i na jej terenie zamieszkiwał w Błoniu, Szynwałdzie i Białej Niżnej, odwiedzając często przebywającego w Ujanowicach swego serdecznego przyjaciela ks. Stacha. Omawiał z nim i ze swoim uczniem ks. Smereką, który także znajdował się w Ujanowicach, różne kwestie naukowe i organizacyjne podziemnego nauczania. W czasie pobytu w Szynwałdzie mieszkał u Sióstr Służebniczek, prowadząc tajne nauczanie i pomagając niektórym swoim podopiecznym ukończyć gimnazjum. W Białej Niżnej był egzaminatorem przy maturze, a do ówczesnych jego uczniów należeli ks. biskup Gucwa, sufragan tarnowski, i ks. prof. Józef Homerski. Przez pewien czas był kapelanem u Sióstr Dominikanek w Białej Niżnej, sprawując nad nimi opiekę duchową. O wielkim poczuciu obowiązku, z jakim wypełniał przyjęte zadanie, świadczyć może dobrze fakt, że już o godz. 4.45 był w kaplicy, a o godz. 5-tej poddawał swym podopiecznym punkty dla rozmyślań i ćwiczeń duchownych, dbając o przestrzeganie przez Siostry surowej reguły zakonnej.

Od roku 1945 zamieszkał w Krakowie, gdzie na Wydziale Teologicznym Uniwersytetu Jagiellońskiego otrzymał katedrę Starego Testamentu. Jako uczony i kapłan rozpoczął ks. Klawek trzeci okres życia. Od razu rzucił się w wir pracy, z wielką energią przystąpił do działalności naukowej, dydaktycznej i organizacyjnej. Przy współudziale ks. Władysława Wichra zorganizował w 1946 r. pierwszy powojenny zjazd naukowy Polskiego Towarzystwa Teologicznego w Lublinie, który był przeglądem i stwierdzeniem strat, poniesionych w czasie II wojny światowej, a zarazem pierwszym nawiązaniem łączności między teologami rozproszonymi w latach okupacji 12. Drugi zjazd Towarzystwa zorganizował ks. Klawek w Krakowie w 1948 r., łącząc go z 550 rocznicą Wydziału Teologicznego UJ. Już wtedy myślał o odpowiednim zorganizowaniu zbliżającej się 1000-letniej rocznicy chrztu Polski i w tym celu prosił ks. Józefa Nowackiego, znanego historyka z Poznania, o wygłoszenie referatu pt. Zadanie nasze wobec nadchodzacego tysiaclecia chrztu Polski. Obchodzony w czasie trwania tego zjazdu jubileusz Wydziału Teologicznego UJ miał

12 Ks. Stanisław Grzybek, art. cyt., 262. 
bardzo uroczysty charakter. Rozpoczął się nabożeństwem w kościele św. Anny, gdzie ks. biskup Stanisław Rospond odprawił mszę św., a ordynariusz $z$ Pelplina wygłosił kazanie. Inauguracyjne zebranie, któremu przewodniczył metropolita krakowski Adam Stefan kardynał Sapieha, odbyło się w auli uniwersytetu.

$\mathrm{Na}$ omawianym zjeździe $\mathrm{z}$ inicjatywy ks. Klawka, zebrani uchwalili dwie interesujące rezolucje, skierowane do Episkopatu Polski, a mianowicie:

1) by Episkopat wyjednał u papieża zezwolenie na używanie języka polskiego w czasie mszy świętej, przy udzielaniu sakramentów świętych i przy obrzędach pogrzebowych, oraz

2) aby podjąć akcję skatalogowania wszystkich rękopiśmiennych i drukowanych tekstów Pisma św. do XVI w. włącznie, znajdujących się na probostwach i w klasztorach.

Jak wiemy, rezolucja o wprowadzeniu języka ojczystego do liturgii uzyskała całkowitą realizację po uchwałach II Soboru Watykańskiego. $\mathrm{Na}$ tym przykładzie widać wyraźnie, jak dobrze ks. Klawek rozumiał współczesne potrzeby wiernych i Kościoła.

Inną wielką akcją ks. Klawka było zorganizowanie przez Wydział Teologiczny UJ w 1949 r. jubileuszu z okazji 350-lecia ukazania się drukiem Biblii w przekładzie ks. Jakuba Wujka. Wraz z obchodami ku czci ks. Wujka odbył się wówczas zjazd biblistów z całej Polski. Obrady odbywały się w kolegium ks. ks. Jezuitów przy ul. Kopernika, a jednym z punktów obchodów było umieszczenie na zewnętrznym murze kościoła św. Barbary tablicy z płaskorzeźbą ks. Jakuba Wujka. Aktu poświęcenia tej tablicy dokonał 22 listopada 1949 r. ks. kardynał Sapieha. Równocześnie w gmachu Biblioteki Jagiellońskiej zorganizowana została wspaniała wystawa biblijna. Ks. Klawek prowadził też starania celem odbudowania zniszczonego przez Niemców pomnika ks. Wujka w jego rodzinnym Wągrowcu. Niestety zabiegi te, skutkiem niezrozumienia u odpowiednich władz, nie przyniosły pozytywnego rezultatu.

W latach 1948-1952 był dziekanem Wydziału Teologicznego UJ i w tym krótkim czasie położył wiele zasług dla reorganizacji i rozwoju zarówno całego wydziału, jak i umiłowanej swej dyscypliny — biblistyki. Wprowadził wiele nowych wykładów, postarał się o obsadzenie opróżnionych katedr, wskrzesił wydawane przez profesorów wydziału pismo „Polonia Sacra”, a także założył w 1948 r. nowe czasopismo - dwumiesięcznik „Ruch Biblijny i Liturgiczny”, którego redaktorem naczelnym był do 1954 r., a następnie stałym współpracownikiem już nowego zespołu ${ }^{13}$. Wspólnie z ks. ks. Ferdynandem Machayem i Stefanem Ma- 
zankiem założył „Wydawnictwo Mariackie”, którego celem było religijne uświadamianie szerokich rzesz wiernych.

Po rozwiązaniu Wydziału Teologicznego UJ wykładał biblistykę w Seminarium Krakowskim, Śląskim i Częstochowskim, a równocześnie prowadził wykłady $\mathrm{z}$ filologii semickiej na Wydziale Humanistycznym UJ. Pracy też nie przerwał nawet po roku 1966, kiedy przeszedł na emeryturę.

W ciągu swojej długiej działalności uniwersyteckiej miał wielu słuchaczy - można się ich doliczyć ponad 2 tysiące. Należeli do nich nie tylko uczniowie z Polski, ale także z Rumunii i ze Stanów Zjednoczonych, byli wśród nich księża i ludzie świeccy. W okresie powojennym skupiło się wokół niego tak wielu uczniów, że można mówić o krakowskiej szkole biblistycznej, stworzonej przez ks. Klawka. Około 40 wykładowców Pisma św. z różnych Instytutów Teologicznych, z Warszawy, Krakowa, Lublina, Poznania. Gniezna, Wrocławia, Opola, Tarnowa - to jego uczniowie. Wielu stawiało swe pierwsze kroki $\mathrm{w}$ biblistyce broniąc $\mathrm{u}$ niego rozpraw doktorskich, a 16 docentów zostało przez niego habilitowanych. Młodych kleryków onieśmielał, a czasem nawet przerażał swą erudycją, dla doktorantów był doskonałym mistrzem, świetnym kierownikiem i troskliwym opiekunem. Umiał zainteresować pracą naukową, zapraszał do siebie i pożyczał ze swej bogatej prywatnej biblioteki książki potrzebne do pracy. Dążył stale do tego, by naszym studiom teologicznym zapewnić wysoki poziom. Zachęcał do opracowywania coraz to nowych problemów. Sam posiadał umysł chłonny, krytyczny, jasny i oryginalny. Nowe myśli, nowe zagadnienia były jego pasją. Dzięki tym wszystkim przymiotom intelektu był przez wszystkich bardzo ceniony, zawsze w dyskusjach liczono się z jego zdaniem. Dzięki tym przymiotom był też zawsze podziwiany, umiał bowiem jasno sformułować wartościowe uwagi i wydobyć istotne myśli z lektury czy wysłuchanego referatu. Pełen precyzji i konsekwencji logicznej w dyskusji umiał zawsze znaleźć właściwe argumenty.

Był teologiem-biblistą torującym nowe drogi. Wykłady i referaty wygłaszał zazwyczaj z pamięci, mając jedynie przed sobą kilka małych karteczek z dyspozycjami i głównymi myślami, na które chciał położyć nacisk. Do tych notatek zaglądał rzadko, co dobitnie świadczyło o tym, że wykład czy prelekcja były poprzednio przez niego dokładnie przemyślane, choć w czasie wykładu potrafił wykorzystać w postaci dygresji nowo nasuwającą się myśl. Uwzględniał osiągnięcia teologii protestanckiej, zwłaszcza biblistyki, celem mocniejszego podbudowania egzegezy katolickiej. Jego wykłady, mimo zaskakujących nieraz nowych poglądów, owiane były duchem głębokiej wiary oraz szacunku dla Bożego misterium, zawartego w księgach świętych. Był dobrym synem Kościoła i charakteryzował się dużym przywiązaniem do Stolicy Apostolskiej. Cieszył 
się, że pewne jego poglądy i myśli, które głosił jako młody kapłan w Poznaniu, a potem we Lwowie i w Krakowie, znalazły potwierdzenie i realizację w dokumentach II Soboru Watykańskiego.

Odnosił w życiu wspaniałe sukcesy, ale ponosił i klęski. Dużo zwłaszcza wycierpiał w ciężkich latach 1948-1952, gdy był dziekanem Wydziału Teologicznego UJ. Tajemnicę jednak tych ciężkich chwil zabrał ze sobą do grobu. Znana była jego niechęć do wywnętrzania się, nie lubił, by mu zaglądano do duszy. Gdy go spotkało jakieś niepowodzenie lub przykrość dłużej klęczał w kaplicy lub kościele. Był pobożny, ale pobożność jego nie miała nic z ostentacji, była bardzo wewnętrzna i jakby zazdrośnie przez niego strzeżona przed okiem ludzkim. Do wielu charakterystyk i zasług ks. Klawka, napisanych przez jego uczniów i przyjaciół, niech wolno tu będzie dodać uwagi dwóch jego najmłodszych uczniów biblisty ks. Jerzego Chmiela i orientalisty dra Andrzeja Zaborskiego. Pierwszy w związku z zasługami ks. Klawka dla biblistyki napisał: „Ks. prof. Klawek wygrał bitwę o Biblię. O jej rozumienie. A wygrał ją bez pisania wielkich manifestów lub buńczucznych założeń metodologicznych. Posiadał jak mało kto z biblistów polskich doskonałe przygotowanie filologiczne. Wyniósł dużą kulturę humanistyczną. Te naczelne a wyjątkowo bogate wyposażenia decydują o charakterze jego prac" ${ }^{14}$. Drugi, ostatni doktor ks. Klawka, wspomina: „Wiele z Jego działalności pozostanie tylko w tych, którzy znali Go bezpośrednio i byli pod wpływem Jego niezwykłej osobowości. Powtarzał, że nie ma dzieł i rozwiązań ostatecznych, że każde osiągnięcie jest tylko pewnym ogniwem, etapem w rozwoju człowieka i jego postępie. Jego własna działalność była godnym podziwu i szacunku etapem, punktem wyjścia dla innych" ${ }^{15}$.

Spoczął ks. Klawek na cmentarzu w rodzinnym Rogoźnie. Na rodzinnym grobie stoi skromny nagrobek. Na krzyżu wyryty starochrześcijański monogram Chrystusa PAX a u jego podstawy prosty napis R.I.P. Rodzina Klawków. Napis ten objęty jest dwoma greckimi literami Alfa i Omega, symbolami naszego Zbawcy, którego Ewengelii ks. Klawek swe życie poświęcił ${ }^{16}$.

14 Ks. Jerzy Chmiel, Mentalność biblisty, RBiL XXIII, 1970, 301.

15 Andrzej Zaborski, Filolog i nauczyciel, RBiL XXIII, 1970, 297.

16 Szersze opracowanie działalności ks. Klawka jako teologa i biblisty ukaże się później w druku. Spuściznę naukową obejmującą kilkaset pozycji bibliograficznych zestawił $\mathrm{Zdz}$ isław J. Kapera, Bibliografia prac księdza Aleksego Klawka (1890-1969), Profesora UJK $i$ UJ, RBiL XXIII, 1970, 319-336. 


\section{RES U ME}

\section{L'ABBE ALEKSY KLAWEK - GRAND BIBLISTE POLONAIS}

Né en 1890 à Rogoźno (La Grande Pologne), décédé le 22 novembre $\overline{1969}$ à Katowice, Monsieur l'Abbé Aleksy Klawek fut un des plus connus biblistes polonais.

Les études secondaires, il les accomplit dans sa ville natale, située à l'époque sur les territoires annexés par la Prusse; la préparation théologique, il la reçut au Séminaire de Poznań, et l'approfondit à Münster et à München, et plus tard à Berlin, à Wrocław et à Paris. Le 15 février 1913, il fit ordonné prêtre, et, après une courte période de l'activité pastorale dans une paroisse, il se rendit à l'étranger pour continuer ses études, couronnées par le doctorat en théologie en 1917 d'après la thèse, intitulée: "Gebet zu Jesus". Dans les années 1917-19, le jeune docteur en théologie prépara son étude d'habilitation, dont la première partie fut imprimée sous le titre: „La nuit de Bethléem. L'histoire ou légende?” à Poznań en 1921. La première ainsi que la deuxième étude prouvèrent incontestablement qu'à l'horizon polonais apparut un bibliste parfaitement préparé à son métier. Dès 1919, il fut professeur de l'Ecriture Sainte au Séminaire Diocésain à Gniezno, puis à Poznań, où il contribua parfaitement à la création de la Commission Théologique de la Société des Amis des Sciences de Poznań. Appelé en 1923 par l'Université de Jean Casimir à Lwów pour donner des cours de l'exégèse de l'Ancien Testament, il occupa ce poste durant 16 années, d'abord comme professeur sans chaire, puis comme professeur titulaire. Dans certain temps, il exerça aussi la charge du doyen de la Faculté Théologique, et celle du vice-recteur de l'Université.

A cette époque, Aleksy Klawek développa l'activité très poussèe, non seulement l'activité scientifique mais aussi celle d'organisateur, et cette dernière aussi bien dans le domaine de sa spécialisation, comme rédacteur du périodique „Revue Théologique" (changé en 1931 en „Collectanea Theologica”) et comme secrétaire général de la Société Théologique de Pologne, que parmi les étudiants, en organisant la pastorale estudiantine et l'aide sociale de l'étendue très large.

Les années de l'occupation hitlérienne, après un court séjour au prison, il les passa dans le diocèse de Tarnów comme directeur spirituel des religieuses, Dominicaines et Servantes de Sainte Vierge d'Immaculée Conception.

Nommé en 1945 professeur de la Faculté Théologique de l'Université Jagellonne à Cracovie, il reprit la chaire de l'exégèse de l'Ancien Testament et recommença l'organisation de l'activité scientifique des théologiens polonais, dissipés par les années de guerre et d'occupation. En 1946 et 1948, il organisa les congrès scientifiques de la Société Théologique de Pologne à Lublin et à Kraków. Cette dernière fut consacrée à la 550ème anniversaire de la fondation de la Faculté Théologique de l'Université Jagellonne et à la 350ème anniversaire de la première édition de la Bible de Wujek. Klawek fit revivre un périodique: „Polonia Sacra”, et créa en 1948 une nouvelle publication bimensuelle: „Revue Biblique et Liturgique".

Lui-même publiait souvent, aussi bien des travaux vulgarisateurs que des traductions, dans le domaine de l'Ecriture Sainte, et surtout dans le domaine du Psautier et des Prophètes. Il insista sur la nécessité de la préparation de ia nouvelle traduction polonaise de la Bible. Grand érudit dans le domaine des antiquités hébraïques et sémitiques, il s'efforçait d'être occurant à chaque moment dans la littérature scientifique, si vaste et si augmentante de jour en jour. Phi- 
lologue hebraïste réputé, il savait d'apprécier l'importance des nouvelles recherches dans cette branche de science, et, plusieurs ans avant le Concile de Vatican II, il indiqua le poids de la théorie des genres littéraires dans la propre compréhension de l'Ecriture Sainte.

Il se réjouit d'avoir le don si rare de saisir le hic du problème et de le présenter d'une manière claire. Il fut l'homme de la grande probité, et ferme dans ses convictions, ce que ne plaisait pas toujours aux hommes qui pensaient différemment. En tant que prêtre, il se distingait d'une grande piété, en tant qu'homme - d'une serviabilité et d'un sens d'organisation; comme savant - de l'érudition et de la largeur des intérêts, comme Polonais enfin - d'un patriotisme. Il a laissé, à côté de ses plusieures oeuvres scientifiques, un cercle de nombreux élèves-biblistes, dont on peut sincèrement affirmer qu'ils forment, grâce à leur maître, la première école biblique en Pologne. 